\title{
CAMBRIDGE UNIVERSITY NATURAL RADIOCARBON MEASUREMENTS VI
}

\author{
H. GODWIN and E. H. WILLIS \\ Cambridge University* \\ INTRODUCTION
}

The dates and activity measurements given below have been obtained during 1962 and 1963, and have been made with $\mathrm{CO}_{2}$ at 3 atm pressure in a proportional gas-counter very little modified from those described in previous contributions from this laboratory.

As hitherto, we have concentrated largely upon determinations essential to research projects being pursued in the University Sub-department of Quaternary Research. We have also undertaken a series of measurements of $\mathrm{C}^{14}$ in the lower stratosphere over the period March 1962 to April 1963 following resumption of testing of thermo-nuclear weapons in late 1961; this work was done in conjunction with Dr. A. G. Maddock of the University Department of Chemistry, and with the assistance of Dr. F. Alonso.

We particularly wish to acknowledge the help of R. J. F. Burleigh, Technical Assistant in the Radiocarbon Dating Laboratory until November, 1962 and G. A. Sutton, who has succeeded him.

\section{SAMPLE DESCRIPTIONS}

BRITISH ISLES

\section{A. Weichselian (Last Glaciation)}

Radiocarbon dates have been sought for several plant-bearing organic deposits in SE England. The question is whether the $\mathrm{C}^{14}$ dates appear to cluster upon periods hitherto associated with climatically determined interstadia, or are so scattered as to suggest that deposits are local incidents of incorporation. If the latter, then the abundant floristic and faunal remains can be taken as representative of organic life that persisted through the last British glaciation south of the ice margin.

\section{Q-590. Barnwell Station, Cambridge $\quad 19,500 \pm 650$}

Plant detritus washed from calcareous marl and leached with $\mathbf{1 7 , 5 5 0}$. $11^{\prime} \mathrm{N} \mathrm{Lat,} 0^{\circ} 07^{\prime} \mathrm{E}$ Long). Gravels of the lowest terrace of the River Cam contain bones of reindeer and mammoth and are overlain by sandy marls with peaty seams rich in plant material from which Miss Chandler (1921) id. a rich periglacial flora including arctic birch and willow. Columella columella is also characteristic of deposits. Biotic assemblages resemble those of Lea Valley Arctic plant bed (Q-25, 28,000 \pm 150 B.P., Cambridge II), although perhaps indicative of somewhat colder conditions. Deposits are now destroyed; sample had been coll. and stored many years previously. Coll. by H. Godwin.

* Radiocarbon Dating Laboratory, 5 Salisbury Villas, Station Road, Cambridge, and University Sub-department of Quaternary Research, Botany School, Cambridge, England. 
Q-657. Broome Heath, Norfolk. Sample A

Drift mud with twigs, leaves etc., and laminae of silt $\left(52^{\circ} 28^{\prime} 40^{\prime \prime} \mathrm{N}\right.$ Lat, $1^{\circ} 27^{\prime} 45^{\prime \prime}$ E Long). Found on surface after excavation by mechanical digger from below 10 to $30 \mathrm{ft}$ of gravel. Probably a fluvioglacial deposit of the last or penultimate (Gipping) glaciation. Plant remains show rich periglacial flora. Coll. 1959 by R. G. West, Botany School, Cambridge. Comment: see note on Q.740.

\section{Q-740. Broome Heath, Norfolk. Sample B}

Organic remains sieved out from drift mud with twigs, leaves etc., and laminae of silt $\left(52^{\circ} 28^{\prime} 40^{\prime \prime} \mathrm{N}\right.$ Lat, $1^{\circ} 27^{\prime} 45^{\prime \prime} \mathrm{E}$ Long). Same provenance as Q-657 above. Coll. 1959 by R. G. West. Comment: sieved and washed plant remains will be more trustworthy than unsorted and possibly contaminated unsieved material of Q-657; therefore an age greater than $40,000 \mathrm{yr}$ is probable for both samples.

\section{B. Late Weichselian}

\section{Roddan's Port Series, Co. Down, Northern Ireland}

During 1957 and 1958 research workers at Queen's Univ., Belfast investigated a coastal exposure of organic deposits laid down in inter-drumlin hollows and subsequently covered by lagoon clay, sands and gravels of the $25 \mathrm{ft}$ raised beach. Site is at Roddan's Port $\left(54^{\circ} 31^{\prime} \mathrm{N}\right.$ Lat, $5^{\circ} 31^{\prime} \mathrm{W}$ Long), in Co. Down. Characteristic tripartite stratigraphy of $\mathrm{W}$ European Late-glacial was exhibited in a sequence from below upwards of grey clay, organic muds $(40$ to $50 \mathrm{~cm})$, and solifluxion clay $(80$ to $90 \mathrm{~cm})$, succeeded by organic muds going over into Phragmites peat. After preliminary pollen-analyses had confirmed age of deposits, a substantial monolith was taken through the beds; careful pollenanalyses were made at Belfast by M. E. S. Morrison at close intervals all through it. With the completed pollen diagrams before us, slices, usually 1 or $2 \mathrm{~cm}$ thick, were cut from chosen levels in the monolith and were brought for $\mathrm{C}^{14}$ assay to Cambridge. It was hoped that samples through lower organic mud would give date and length of the mild Alleröd interstadial, and that samples from upper organic bed would give local dates of pollen zone boundaries. Samples are given in strict stratigraphic sequence from below upwards, with local index numbers appended; these are based on centimeter measurements but do not follow a strict sequence.

\section{Q-360. Roddan's Port, Co. Down (R $2962 \quad 12,110 \pm 190$} + 2963) $\quad$ 10,160 в.c.

Grey freshwater or brackish water clay with some organic content, near top of Zone I, periglacial flora with Salix pollen maximum and abundant Potamogeton pollen.

\section{Q-358. Roddan's Port, Co. Down (R $2967 \quad 11,950 \pm 190$ $+2968)$ \\ 10,000 B.c.}

Compressed detritus mud from bottom $2 \mathrm{~cm}$ of organic layer, taken as top of Zone I ( pollen) or base of Zone II (lithology). Beginning of rise of pollen curves of Juniperus and Empetrum: high Rumex. 
Q-359. 11,845 \pm 190

Q-359. Roddan's Port, Co. Down (R $2969 \quad 11,830 \pm 190$ +2970 )

9895 в.с.

9880 в.C.

Organic mud from base of Zone II and immediately above Q-358.
Q-361. Roddan's Port, Co. Down (R $2980 \quad 12,090 \pm 190$ +2981 )
10,140 в.с.

Organic mud about two thirds down Zone II muds at horizon of Rumex pollen decrease.

Q-362. Roddan's Port, Co. Down (R 2982 +2983 )

$11,390 \pm 190$

Organic mud, immediately above Q-361.

Q-363. Roddan's Port, Co. Down (R 2991) $\quad 11,450 \pm 190$

Organic mud from near middle of Zone II, horizon of decrease Juniperus.

\section{Q-364. Roddan's Port, Co. Down (R 3004) $\quad 11,770 \pm 190$ \\ Q.364. Rode B.c.} Organic mud from near top of Zone II, marked lithologically and by rise of pollen of Cruciferae and Caryophyllaceae.

\section{Q-365. Roddan's Port, Co. Down (R 3006) $\quad 11,480 \pm 150$}

Transition from organic mud to solifluxion clay at Zone II/III transition, and $2 \mathrm{~cm}$ above Q-364.

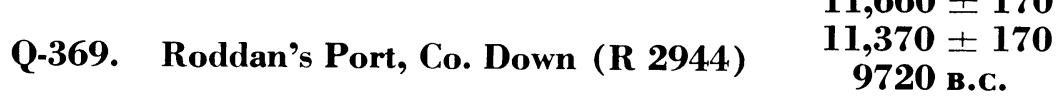 \\ 9420 в.c.}

Boundary between solifluxion clay and overlying organic mud, base of Morrison's transition Sub-zone III/IV in which pollen of open habitats remains abundant before the expansion of birch woodland.

\section{Q-370. Roddan's Port, Co. Down (R $2945 \quad 10,070 \pm 150$ $+2946)$ \\ 8120 в.C.}

Organic mud at base of Sub-zone III/IV as Q-369 and immediately above that sample.

\section{Q-371. Roddan's Port, Co. Down (R 2954)}

$10,130 \pm 170$ 8180 в.C.

Phragmiles peat from base of Morrison's Zone IV marked by rise in pollen frequencies of Betula, Juniper, Salix and Tree-shrub/Herbaceous pollen ratio.

\section{Q-368. Roddan's Port, Co. Down (R 2955)}

$$
\begin{aligned}
& 10,210 \pm 150 \\
& 8260 \text { в.c. }
\end{aligned}
$$

Phragmites peat from middle of Zone IV, marked by fall in Betula and Salix curves and rise in Gramineae-possibly only local. 
Q-366. Roddan's Port, Co. Down (R 13)

$9430 \pm 150$ Corlus pollen peat at Zone IV/N transition, marked by sudden expansion of of Betula: rise of tree and shrub pollen to complete dominance.

\section{Q-367. Roddan's Port, Co. Down (R 10)}

$9090 \pm 150$

7140 в.c.

Phragmites peat at Zone V/VI transition at beginning of curves for Ulmus and Quercus pollen.

Comment: last four samples in scries, all in Phragmites peat, yield values gencrally in accord with dates hitherto found in Britain for the earliest postglacial pollen-zones: thus Scaleby Moss (Cambridge I; Godwin, Walker and Willis, 1957).

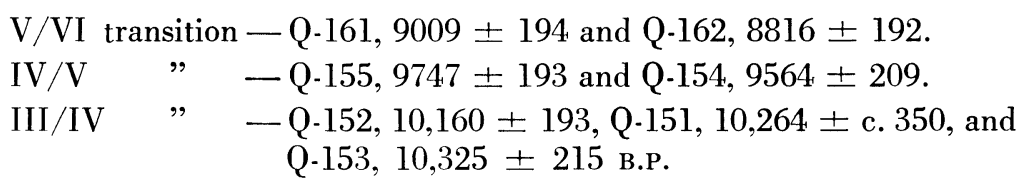

The two adjacent samples Q-369 and Q-370 have yielded dates widely out of agreement despite repeated checks. That for Q-370 is closest to expectation of Zone III/IV boundary date, but low assay of Q-369 is unexplained.

Samples Q-360, Q-358, Q-359 that cover the I/II Zone boundary give th? expected date ca. 12,000 B.P. Likewise Q-362 and Q-363 have given dates expected for middle of Zone II. Sample Q-361, subjacent to Q-362, yields a far older date, and likewise samples Q-364 and Q-365 are older than expected, Q-364 having a determined age greater than that of samples considerably below it in the section. These unexpectedly great ages are probably the result of incorporation of inactive carbon in the organic muds, the 'hard-water error', a suggestion borne out by presence of Chara and fresh water mollusca in these open water muds. Erratic incidence of this presumed error is noteworthy, and reinforces the untrustworthiness of some organic muds for dating purposes.

Although close dating of late-glacial zone boundaries has not been realized, and although method lacks the sensitivity needed to date small sub-zones, such as the suggested III/IV transition zone, there is a good deal of correspondence with late-glacial zone boundary hitherto obtained for Britain (Godwin and Willis, 1959).

\section{Bigholm Burn series, Dumf riesshire, Scotland}

Stream erosion exposed an important section on E bank of Bigholm Burn, Dumfriesshire ( $55^{\circ} 07^{\prime} 15^{\prime \prime} \mathrm{N}$ Lat, $3^{\circ} 04^{\prime} 30^{\prime \prime} \mathrm{W}$ Long) Natl. Grid Ref. 316812 , alt ca. $480 \mathrm{ft}$ O.D., $4 \mathrm{mi} \mathrm{SW}$ of Langholm. It has been fully investigated by Neville T. Moar of Cambridge Sub-dept. of Quaternary Research, who coll. the samples in 1962.

Oldest beds in section are varved clays; as the lake shallowed these were replaced by a thin layer of organic muds (No. 1). This stage ended with deposition of solifluxion gravels ca. $1 \mathrm{~m}$ thick, enclosing a lens of silty organic mud $70 \mathrm{~cm}$ from its base (No. 2). On the surface of the solifluxion gravels 
organic muds were laid down, the earliest represented by sample No. 4, and these $(8 \mathrm{~cm})$ pass upwards into dark Phragmites peat $(40 \mathrm{~cm})$ and then compressed wood peat (No. 8) $70 \mathrm{~cm}$ thick. These upper muds and peats have total thickness of ca. $2.5 \mathrm{~m}$, but attention was concentrated on lower beds, for which lithological sequence and pollen analyses indicated a Late-glacial age with the solifluxion gravels possibly referable to Zone III.

\section{Q-694. Bigholm Burn, Dumf riesshire No. 1
$11,820 \pm 180$
$11,580 \pm 180$
9870 в.C.
9630 в.с.

Organic mud from $13 \mathrm{~cm}$ layer below thick solifluxion gravels. Extremely low tree pollen frequencies, very high local frequency of carices; open vegetation of periglacial type indicated. Comment: date corresponds with that of Zone II (Alleröd) deposits elsewhere in Britain.

\section{Q-695. Bigholm Burn, Dumf riesshire No, $2 \quad 10,820 \pm 170$}

Basal $6 \mathrm{~cm}$ of silty organic mud lens $10 \mathrm{~cm}$ thick in the solifluxion gravels. Pollen spectra similar to those of Q-694. Comment: date corresponds with middle Zone III dates in Britain.

\section{Q-697. Bigholm Burn, Dumf riesshire No. 4 \\ $9590 \pm 170$ \\ $9470 \pm 170$ \\ 7640 в.C. \\ 7520 в.с.}

Brown organic mud layer, $8 \mathrm{~cm}$ thick, directly overlying solifluxion gravels, with pollen representing a rich but open periglacial vegetation including much Juniperus and Salix, but few trees; high frequencies of pollen of Myriophyllum alterniflorum. Comment: date is considerably younger than Zone III/IV transition, and may indicate local delay in deposition of organic muds after the cold period represented by solifluxion gravels.

\section{Q-701. Bigholm Burn, Dumfriesshire No. 8}

$$
7640 \pm 160
$$

5690 в.c.

Dark brown woody peat (Betula) from basal part of wood layer. Beginning of rise of pollen curves of Quercus and Ulmus and just before maximum of Corylus, i.e., opening of Zone VI. Comment: date is much younger than V/VI Zone transition previously recorded (e.g. Scaleby Moss) and it is possible that growth of birch trees in situ in Zone VIc has led to disappearance of a large part of Zone VI.

\section{Q-673. Kirkmichael, Isle of Man. Site $3 \quad 10,270 \pm 170$ \\ "Peat" from coastal cliff section (54 ${ }^{\circ} 17^{\prime} \mathrm{N}$ Lat, $4^{\circ} 35^{\prime} \mathrm{W}$ Long) Natl.} Grid Ref. 312909. The section reported by G. F. Mitchell of Trinity College, Dublin is as follows: 0 to $1450 \mathrm{~cm}$, gravels forming terrace at top; 1450 to $1458 \mathrm{~cm}$, sandy clay with vegetable debris (dated sample); 1458 to $1565 \mathrm{~cm}$, sandy chalk mud; 1565 to $1567 \mathrm{~cm}$, non-calcareous organic mud; 1567 to $2177 \mathrm{~cm}$, cryoturbated gravel; 2177 to $2377 \mathrm{~cm}$, boulder clay cryoturbated on top; 2377 to $4077 \mathrm{~cm}$, gravels and boulder clays, the lowermost believed to be of Gipping age. 
Macroscopic plant remains in vegetable layer indicate periglacial conditions including Salix herbacea, Selaginella selaginoides, etc. Sample will test age of gravel infill. Coll. 1962 by G. F. Mitchell, Trinity College, Dublin. Comment: $\mathrm{C}^{14}$ age is very close to that generally found for the end of Zone III. The great depth of gravel above it indicates remarkable infilling activity that correlates best with Zone III itself.

\section{Q-758. Blelham Tarn, Lancashire, W Kettlehole, $\quad 14,330 \pm 230$ $432 / 9 \mathrm{~cm}$$$
14,280 \pm 230
$$$$
12,380 \text { в.С. }
$$$$
12,330 \text { в.c. }
$$

Detritus nekron mud from NW margin of Blelham Tarn $\left(54^{\circ} 23^{\prime} \mathrm{N}\right.$ Lat, $2^{\circ} 59^{\prime} \mathrm{W}$ Long), Natl. Grid Ref. 35/365006, alt $138 \mathrm{ft}$ O.D., 13/4 mi NE of Hawkshead. Stratigraphy, first recognized by Frank Oldfield, was checked by a second Hiller boring by G. $\mathrm{H}$. Evans, who later recovered it in a $\mathrm{C}^{14}$ corer of wider diam. Sequence is as follows: to $400 \mathrm{~cm}$, Postglacial nekron muds and peats and Zone III grey clay; 400 to $427 \mathrm{~cm}$, fine detritus silty nekron mud (presumed Zone II) ; 427 to $432 \mathrm{~cm}$, grey silt (presumed Zone I) ; 432 to $438 \mathrm{~cm}$, greasy micro-laminated detritus silty nekron mud ( $\mathrm{C}^{14}$ sample); 438 to $450 \mathrm{~cm}$, blue-grey clay; $450 \mathrm{~cm}$ on, gravels.

Pollen analyses carried out by Mr. Evans (in conjunction with diatom analyses) clearly indicate presence of Zone II and Zone III deposits beneath early postglacial muds. The microlaminated mud (432 to $438 \mathrm{~cm}$ ) differs lithologically and pollen-analytically from Zone II deposits here and elsewhere in the region and should probably be referred to Zone I. This is supported by the very high ratio for Rumex pollen in it along with the usual periglacial assemblage, and by the great decrease in the AP/NAP ratio in the grey silty layer overlying it $(427$ to $432 \mathrm{~cm})$. Coll. summer 1963 by G. H. Evans of Sub-dept. of Quaternary Research, Cambridge. W. Tutin of Univ. of Leicester is pursuing more detailed pollen analyses on these deposits. Comment: $\mathrm{C}^{14}$ date unequivocally places sample in Zone I, ca. 1000 yr before any part of Zone II; deposit is quite non-calcareous and possibility of a hard-water error is slight.

\section{Q-643. Roberthill, near Lockerbie, Dumfriesshire $\quad 12,940 \pm 250$ \\ 10,990 в.C.}

Wood (55 $06^{\prime}$ N Lat, $3^{\circ} 24^{\prime}$ W Long), Natl. Grid Ref. 35/110794, from a $1 \mathrm{ft}$ bed of silty detrital peat occurring $3 \mathrm{ft}$ from the base and within parallel bedded grey clays, silts and fine sands, at least $14 \mathrm{ft}$ in thickness, exposed in E bank of River Annan at Roberthill. These still-water deposits probably originated in a former "Loch Maben," remnants of which can be seen locally; they become sandier towards the top and overlie clean unconsolidated ochreous gravels possibly of fluvio-glacial origin. Pollen-analyses by Neville Moar from four levels in the peat indicate an open landscape with stands of Betula (and much B. nana), Salix and Juniperus, with an assemblage of plants characteristic of the British Late-glacial, such as Hippophae rhamnoides, Armeria maritima and the genera Helianthemum, Thalictrum and Urtica. Coll. 1961 by W. W. Bishop, Uganda Mus., Kampala. Comment: $\mathrm{C}^{14}$ age suggests reference to Pollen Zone I and this agrees well with lithology and pollen-analytic indications. Accumulation of peat layer may point to temporary climatic 
amelioration or merely to local conditions permitting growth of aquatic vegetation.

\section{Postglacial Vegetational history}

A primary objective of the Cambridge Sub-dept. of Quaternary Research has been to establish by pollen analysis the detailed picture of postglacial vegetational history in Britain, and it is thus essential to secure $\mathrm{C}^{14}$ dates on pollen-zone boundaries at widely spread sites. We have made use of an extracted monolith wherever possible (as in the Roddan's Port series, see above) or of the core from a wide diam borer, from which a transverse slice 1 or 2 $\mathrm{cm}$ thick will yield a clean sample big enough for $\mathrm{C}^{14}$ assay. We are often able to date vegetational zones by series of pollen-dated samples secured in investigations also involving other major correlations, such as Mesolithic archaeology in the Thatcham series which follows, and land-sealevel changes in the PortTalbot sequence.

\section{Thatcham, Berkshire series}

From 1922 onwards the gravel terrace beside the River Kennet 1 mi ESE of Thatcham, Berkshire $\left(51^{\circ} 24^{\prime} \mathrm{N}\right.$ Lat, $1^{\circ} 17^{\prime} \mathrm{W}$ Long), has yielded abundant evidence of occupation by Mesolithic man. Although artifacts were abundant on the terrace surface itself, dating of them depended largely upon their recovery from a stratified deposit; thus during the summer of 1961 a coffer dam was sunk into swamp sediments at the foot of the terrace and contents were excavated by a team led by J. J. Wymer of the Reading Mus. D. M. Churchill (Sub-dept. of Quaternary Research, Cambridge) worked out the stratigraphy. Calcareous marls of the channel permitted pollen-analytic reference to a series of zones, and although the marls themselves were unsuitable for $\mathrm{C}^{14}$ assay, they yielded satisfactory samples of embedded wood (samples Q-650, 651, 652, 677 ). Hearth sites on the terrace were eventually covered by silt and by fen peat which at a later stage dried out to form a hard black aggregate wrongly described in earlier work as 'charcoal'; a $\mathrm{C}^{14}$ date for this peat has already been published (BM-65, $8090 \pm 180$ B.P.). For dating of Mesolithic hearths on the terrace it was important to avoid confusion with this dried peat, and Q-658 and 659 consisted only of partly combusted wood and shells of hazel nuts.

Q-651. Thatcham, Berkshire. Site 5, No. 3

$9840 \pm 160$

7890 в.c.

Wood of Betula and Pinus from level $2 \mathrm{ft} 5$ in. to $2 \mathrm{ft} 11$ in. below top of white algal marl, lowest horizon at which artifacts were found. Pollen analyses indicate Zone IV. Coll. June 1961 by D. M. Churchill.

\section{Q-650. Thatcham, Berkshire. Site 5, No. $2 \quad 9670 \pm 160$}

Black disintegrated wood $2 \mathrm{ft}$ below top of white algal marl. Level contained (Mesolithic) birch bark roll, and pine cones (not combusted). Pollen Zone V. Coll. June 1961 by D. M. Churchill.

Q-677. Thatcham, Berkshire. Site 5, No. 4

$9780 \pm 160$ 7830 в.с.

Fresh wood from same level as Q-650, Pollen Zone VI. Coll. June 1961 by D. M. Churchill. 
Q-652. Thatcham, Berkshire. Site 5, No. 1

Pine wood 9 in. below top of algal marl, Pollen Zone VIa, still within local occupation sequence in coffer dam. Coll. June 1961 by D. M. Churchill.

\section{Q-658. Thatcham, Berkshire. Site 3, No. 1}

$10,030 \pm 170$ 8080 в.с.

Wood partly converted to charcoal and broken shells of hazel nuts (Corylus avellana) from Mesolithic hearth in occupation layer on river terrace (Churchill, 1962; Wymer 1962). Coll. June 1961 by J. J. Wymer, County Mus., Reading.

Q-659. Thatcham, Berkshire. Site 3, No. 2

Charcoal from another Mesolithic hearth in occupation layer on river terrace (Churchill, 1962; Wymer, 1962). Coll. June 1961 by J. J. Wymer. Comment on Thatcham series: evidence of the terrace hearths and of the coffer dam samples together indicates that Mesolithic occupation extended at least from ca. 10,365 to ca. 9480 в.P. Dates from samples within the coffer dam are self-consistent, duplicate runs of Q-652 agree closely, and Q-650 and Q-677 from the same level have given similar dates to one another. When we come to consider the bearing of these dates upon the ages of pollen zones it has first to be noted that the algal marls were so poor in pollen that analyses could be made at only five levels. Thus although the $\mathrm{C}^{14}$ samples fairly certainly refer to Zones IV, V and VI we do not know from what part of the zone each comes; Q-650 and Q-677 may be early in Zone V (which is known to persist 6 in. higher) but we cannot place Q-652 within Zone VIa, or Q-651 within Zone IV. This contrasts sharply with Scaleby Moss (Cambridge I; Godwin, Walker and Willis, 1957) where pollen analyses were at very close intervals and $\mathrm{C}^{14}$ samples were taken in very close relation to zone boundaries. With this in mind we note that date for Zone IV Q-651 (9840 B.P.) corresponds closely with the mean of oldest and youngest dates for Zone IV at Scaleby; (early) Zone V dates for Q-650 and Q.677 (9670 and 9780 в.P.) correspond with date for base of Zone V at Scaleby (Q-155, 9747); Zone VIa date for Q-652 (9480 and 9500 в.P.) falls about $500 \mathrm{yr}$ earlier than the opening of Zone VI at Scaleby (Q-161, 9009 B.P.). This therefore seems good evidence that Zone VI opened earlier in $\mathrm{S}$ Britain than in the north, and that Zone $\mathrm{V}$ lasted longer in the north.

\section{Port Talbot, Glamorgan Series}

Messrs. George Wimpey \& Co. Ltd. in 1960/61 made exploratory borings for a harbour development scheme at Baglan Burrows, near Port Talbot, South Wales $\left(51^{\circ} 52^{\prime} \mathrm{N}\right.$ Lat, $3^{\circ} 48^{\prime} \mathrm{W}$ Long), and in several bores encountered peat beds at considerable depths below present sealevel. They sent us boring logs and peat from some of the cores; we selected two cores (19 and 4) as particularly promising and investigated basal peat from each by pollen-analysis, 
extraction of fruits and seeds, and $\mathrm{C}^{14}$ dating. The basal compacted peat, ca. $20 \mathrm{~cm}$ thick, from bore 19 rested upon dense rounded gravel in a matrix of sandy silt at $-63.1 \mathrm{ft}$ O.D., and was covered by sands and silty clays (result of postglacial marine transgression) to a height of $+24.4 \mathrm{ft}$ O.D. Closely spaced pollen samples through the peat layer showed that it extended from the opening of Pollen Zone IV into Zone VI; samples for $\mathrm{C}^{14}$ dating were therefore taken from four horizons including the three pollen-zone boundaries. Borehole 4 also terminated in a similar gravel at similar depth $(-64.6 \mathrm{ft}$ O.D. $)$ on which rested a peat bed $5 \mathrm{ft}$ thick, succeeded by sands, clays and silts to a height of +28.4 ft O.D. Unfortunately we do not know from what part of the peat bed came the $15 \mathrm{~cm}$ section sent to us; it was remarkable in that continuity of the peat was broken by an irregular transverse wedge of pebbly sand. Again samples for pollen-analysis, fruit and seed extraction, and $\mathrm{C}^{14}$ dating were taken.
Q-660. Port Talbot, Glamorgan, Bore 19, $\quad 10,350 \pm 170$ 4.5 to $6 \mathrm{~cm} \quad 8400$ в.c.

Compressed fresh-water Phragmites peat with bud-scales of Salix and nutlets of Lycopus europaeus, taken at pollen zone boundary III/IV.
Q-661. Port Talbot, Glamorgan, Bore 19, $\quad 9920 \pm 170$ 8.5 to $10 \mathrm{~cm} \quad 7970$ в.c.

Compressed fresh-water peat across pollen zone boundary IV $/ \mathrm{V}$.
Q-662. Port Talbot, Glamorgan, Bore $19 \quad 8990 \pm 170$ 12.5 to $14 \mathrm{~cm}$ 7040 в.C.

Compressed fresh-water peat across pollen zone boundary V/VI.

\section{Q-663. Port Talbot, Glamorgan, Bore 19, 20 to $21 \mathrm{~cm}$ \\ $8970 \pm 160$ \\ 7010 в.с.}

Compressed fresh-water peat within Pollen Zone VI.

Comment on samples from Bore 19: ages for the III/IV and V/VI boundaries are close to those obtained from Scaleby Moss, but that for the IV $/ \mathrm{V}$ boundary is older than corresponding Scaleby date and closer to that indicated for Thatcham by Q-650 and Q-677 (see above). Date for Q-663 is surprisingly close to that of Q-662, which is (in this compressed material) substantially below it. Sample Q-663 indicates that the postglacial eustatic rise of sealevel above-62 ft O.D. on this coast must have taken place after $8970 \pm 160$ B.P., or at this date if no depositional gap exists between the top of this peat bed and overlying marine deposits. Latter view is closely in accord with the identification of a submergence of peat at- $52 \mathrm{ft}$ O.D. in Swansea Bay as within Pollen Zone VIb (Godwin, 1940a) and supplements the general curve of eustatic rise of sealevel which is being progressively defined (Godwin, Suggate and Willis, 1958).

\section{Q-664. Port Talbot, Glamorgan, Bore 4, $12 \mathrm{~cm} 11,980 \pm 180$}

Compressed fine-detritus mud from $5 \mathrm{ft}$ peat bed resting on gravel at -64.6 ft O.D., containing macroscopic remains of Phragmites, tree birch, Typha, Valeriana officinalis, frequent Carex rostrata, Potentilla palustris and abundant Menyanthes trifoliata (i.e., a fen community). Pollen of general late- 
glacial character, a high N.A.P./A.P. ratio and characteristic range of herbaceous pollen types.

\section{Q-665. Port Talbot, Glamorgan, Bore 4, $3 \mathrm{~cm} \quad 11,260 \pm 170$}

Compressed fine-detritus mud taken $9 \mathrm{~cm}$ above Q-664, again with abundant seeds of Menyanthes trifoliata, and a characteristic late-glacial pollen assemblage, but with a higher Betula/Pinus ratio than in lowest sample of bed. Comment on samples from Bore 4: the 4 pollen spectra from this $15 \mathrm{~cm}$ peat bed suggest a late-glacial deposit, presumably of Alleröd age, and this is borne out by the two $\mathrm{C}^{14}$ dates which seem to span the dates given for this stage (Zone II) in the British deposits (Godwin and Willis, 1959). Results do not conflict with the conclusion derived from the Bore 19 samples, that the eustatic rise in ocean level did not affect levels of $-60.0 \mathrm{ft}$ O.D. on this coast until well into the postglacial period. They reinforce conclusions of pollen analysis from Swansea Bay (Godwin, 1940a) and of basal peat layers from other bores at Port Talbot, that upon an irregular surface of drift fresh-water organic muds and peats accumulated locally from Zone II to Zone VI, when the eustatic rise of sealevel intervened. This parallels the development for the drumlin moraine territory of the coast at Roddan's Port (Q-364 to 371). The irregular wedge of pebbly sand that in the core separated Q-664 and Q-665, may be solifluxion material introduced in the succeeding cold Zone II, but precise evidence is lacking.

\section{Archaeologic Samples}

\section{Q-707. Ickornshaw Moor, West Riding, Yorkshire $\quad \mathbf{8 1 0 0} \pm 150$}

Charred hazel nuts (Corylus avellana) (53 $50^{\prime} \mathrm{N}$ Lat, $2^{\circ} 3^{\prime} \mathrm{W}$ Long) Natl. Grid Ref. 959406, 1125 ft O.D. on Aire-Ribble watershed. Closely associated with a Mesolithic industry in chert on surface of mineral soil. Although living roots penetrate to the mineral soil they seem not to affect the nut shells. Coll. Oct. 1962 by J. Davies, 91 Emm Lane, Bradford. Comment: basal peat gives only terminal date for underlying Mesolithic industry on Pennine Hills and strictly contemporary dating material such as this is infrequent. The Mesolithic industry below blanket peat at Stump Cross, near Grassington, Yorkshire (Q-141) had similar age (6500 \pm 310 в.c.).

\section{$\begin{array}{ll}\text { Q-669. Catcott Burtle, Somerset, yew bow } & 3270 \pm 110 \\ & 1320 \text { в.c. }\end{array}$}

Yew wood $\left(51^{\circ} 12^{\prime} \mathrm{N}\right.$ Lat, $2^{\circ} 48^{\prime} \mathrm{W}$ Long), segment cut from a bow now in Taunton County Mus., from peat diggings near Catcott Burtle. Bow is a tapering main stem of yew showing the bases of several whorls of lateral branches (Clark, 1963).

\section{Q-684. Cambridge, yew bow $\quad 3680 \pm 120$

Wood (Taxus) of prehistoric bow $\left(52^{\circ} 11^{\prime} \mathrm{N}\right.$ Lat, $0^{\circ} 07^{\prime} \mathrm{E}$ Long), found deep in the peat near Cambridge in 1885. Now in Pitt Rivers Mus., Oxford. First published by Longman (1894) and bow described by Clark (1963). Forwarded through Grahame Clark by Dennis Britton, Pitt Rivers Mus., Oxford. 


\section{Q-760. Weston Wood, Albany, Surrey, W.W.63; $\quad 2460 \pm 110$ $\operatorname{A12}(\mathbf{P})$ \\ 510 B.c.}

Carbonized cereal grains $\left(51^{\circ} 13^{\prime} \mathrm{N}\right.$ Lat, $0^{\circ} 28^{\prime} \mathrm{W}$ Long) from storage pit of Late Bronze Age homestead, associated with $20 \mathrm{ft}$ diam house, quern house, working floor, cultivated plots, copper, bronze and flint flake tools, and pottery assigned by C. Hawkes to one period ca. 800 to 750 B.c. Cereals include Triticum dicoccum and other sp, and a six-rowed barley (Hordeum). Excavated in May to July 1963, and coll. by Miss J. M. Harding, 57 The Green, Elwell, Surrey for the Surrey Archaeol. Soc.; forwarded by A. H. Bunting, Univ. of Reading. Comment: in good general agreement with expectation, but may point to some small (local) modification of Late Bronze Age chronology.

\section{Monamore, Isle of Arran series}

Euan MacKie of Hunterian Mus., Univ. of Glasgow during June and Sept. 1961 excavated a Neolithic chambered tomb at Monamore, Arran, Buteshire (55 $30^{\prime} 49^{\prime \prime}$ N Lat, $5^{\circ} 8^{\prime} 24^{\prime \prime}$ W Long), Natl. Grid Ref. NS/0172 2887. The Neolithic cairn was built on undisturbed soil, but as result of soil erosion on slopes above, the forecourt was gradually filled with earth so fires periodically lit there were stratified one above the other. Charcoal samples coll. from various levels from base to top, so as to cover whole time of construction and use, but only two proved large enough for $\mathrm{C}^{14}$ assay. Termination of occupation is indicated by the laying down of a stone blocking pavement, which greatly lessens the chance of any subsequent root penetration from above into the forecourt deposits now assayed. Publication by E. MacKie will be in Proc. Soc. Antiq. Scotland, and Antiquity, 1963.

\section{Q-675. Monamore, Arran, Buteshire, No. $2 \quad 5110 \pm 110$}

3160 в.c. um of the forecourt and beneath stones of blocking pavement.

\section{Q-676. Monamore, Arran, Buteshire, No. 3D $\quad 4190 \pm 110$}

Charcoal from Hearth 25 , at depth of $2 \mathrm{ft} 4 \mathrm{in}$ and imm stones of blocking pavement, i.e, at end of occupation.

General Comment (E.M.) : both charcoal samples, probably from the remains of fires, came from deposits which had accumulated in the forecourt after the construction of the cairn and there is therefore little doubt that they date the period of its construction and use. A late 4th millennium B.c. date for the arrival of some of the first agricultural immigrants in southwest Scotland is of interest in that it is closely comparable with the earliest Neolithic dates obtained in southern England. The second date, from just before the final closure of the tomb, seems to imply that this burial cairn was in use for perhaps as much as a thousand years.

\section{Q-672. Westward Ho, Devonshire No. $1 \quad 6585 \pm 130$}

Peat $\left(51^{\circ} 2^{\prime} 30^{\prime \prime} \mathrm{N} \mathrm{Lat}, 4^{\circ} 13^{\prime} 50^{\prime \prime} \mathrm{W}\right.$ Long $)$, uppermost 3 in. of an 8 in. peat bed accumulated on the foreshore above a Mesolithic midden, and part of the submerged forest exposed below mean tide-level. Peat now stands at $-7.0 \mathrm{ft}$ 
O.D., and represents youngest obtainable date prior to submergence. Associated studies of stratigraphy, macro remains and palynology by D. M. Churchill (in press); the Mesolithic industry is referred to by Clark (1955). Coll. Feb. 1962 by D. M. Churchill.

\section{Q-770. Ringneill Quay, Co. Down. Occupation No. $3 \quad 5380 \pm 120$}

Charcoal $\left(54^{\circ} 32^{\prime} \mathrm{N}\right.$ Lat, $5^{\circ} 30^{\prime} \mathrm{W}$ Long) from Mesolithic kitchen midden within $25 \mathrm{ft}$ raised beach on NW shore of Strangford Lough, Northern Ireland. Deposits excavated by Stephens and Collins (1960) and three $\mathrm{C}^{14}$ dates from the site have already been published (Cambridge V). Occupation layer associated with abundant bones of ox, pig, and sheep, lies immediately ahove lagoon clays, assigned to near pollen zone boundary VI/VII and already $\mathrm{C}^{14}$ dated (Q-632, 7345 and $7500 \pm 150$ B.P.). Coll. 1963 by M. Jope, Dept. of Archaeol., The Queen's Univ., Belfast. Comment: dates previously obtained from 'the occupation layer' $(Q-663,3680 \pm 120$ B.P. $)$ and from shells of midden on crest of beach (Q-635, $2660 \pm 110$ B.P.) indicate that beach surface was occupied for a long period but neither date was old enough to correspond with Mesolithic character of the industry described by Stephens and Collins. Therefore, M. Jope sought to recover material unequivocally from Mesolithic occupation level; date now obtained would correspond with Mesolithic/Neolithic transition, as also exhibited by the raised-beach settlement at Dalkey Island, Co. Dublin (D.38, $5300 \pm 170$ B.P., and as perhaps pointed to by the nature of the animal bones (M. Jope's appendix to Stephens and Collins, $1960)$.

\section{Q-530. Freshwater West, Pembrokeshire. 4 to $7 \mathrm{~cm} \quad 5960 \pm 120$ 4010 в.c.}

Wood peat $\left(51^{\circ} 39^{\prime} \mathrm{N}\right.$ Lat, $05^{\circ} 05^{\prime} \mathrm{W}$ Long) from submerged peat at low tide mark on the foreshore, resting upon boulder clay, and associated with a microlithic (Mesolithic) industry (Wainwright, 1960; Leach, 1918; Clark, 1955). Pollen analyses confirm this is a post-Boreal peat (Zone VII or later); macroscopic plant remains indicate fen-wood conditions. Artifacts mostly occurred on clay surface but some were in the basal few $\mathrm{cm}$ of the peat, possibly worked up into it. Coll. 1960 by Geoffrey Wainwright, Inst. of Archaeol., Univ. of London. Comment: $\mathrm{C}^{14}$ date may give actual date of Mesolithic culture, in which case it is quite late (cf. Q-770, Ringneill Quay) or it may give youngest limit only as with Q-672, Westward Ho. Date, however, does not conflict with archaeologic or pollen analytic evidence; its bearing on land and sealevel changes is referred to on p. 126-127.

\section{E. Land-and Sealevel Changes}

Changes of relative land- and sealevel affecting British coasts have been investigated for several years by members of Univ. Sub-dept. of Quaternary Research, Cambridge, with the primary objective of defining and separating the eustatic and other components of such changes (see Cambridge I, III, V and Godwin, 1960). Series reflects the researches of D. M. Churchill upon the relatively recent marine trangressions in $\mathrm{S}$ half of Britain. 


\section{Q-712. Borth Bog, Cardiganshire. No. 1}

Rhizomatous peat ( $52^{\circ} 30^{\prime} 55^{\prime \prime} \mathrm{N}$ Lat, $4^{\circ} 1^{\prime} 43^{\prime \prime} \mathrm{W}$ Long) between Tymar-Mochno and Ynys-las cottage. Sheltered from Cardigan Bay on W by big coastal dune ridge, and in large raised bog whose stratigraphy has been briefly reported (Godwin, 1943). To $\mathrm{N}$ however bog approaches tidal marshes of the River Dovey and borings have established that a wedge of clayey peat with abundant Juncus maritimus rhizomes above Phragmites peat extends at about +7.5 to $+8.5 \mathrm{ft}$ O.D. for some few hundred yards into raised bog peats. Sample is from base of the clayey J. maritimus peat and represents a time near the culmination of a marine transgression. Estuarine origin of the clay is proved by presence of several species of foraminifera (det. Terry Adams, Dept. of Geology, Univ. of Aberystwyth). Coll. April 1963 by D. M. Churchill. Comment: base of raised bog deposits overlies marine clays close to mean sealevel and is taken to be the product of the main eustatic rise in ocean level. Basal layers of the bog have been dated by wood-peat now exposed on the foreshore (Q-380, $6026 \pm 135$; Q-382, $5898 \pm 135)$. Transgression now dated appears to fall in early part of Pollen Zone VIII (increased frequencies of Betula, loss of Tilia, low but maintained values for Fagus). It also overlies a pronounced recurrence surface; $\mathrm{C}^{14}$ date suggests that this cannot be $\mathrm{RY}$ III; it might be RY IV or might merely reflect onset of marine transgression.

Q-691. Llanwern, Nr. Newport, Monmouthshire. No. $1 \underset{710}{2660} \pm 110$

Peat $\left(51^{\circ} 34^{\prime} \mathrm{N}\right.$ Lat, $2^{\circ} 54^{\prime} \mathrm{W}$ Long) at site of new steel mills of Richard Thomas and Baldwins Ltd. from the contact with an overlying marine clay at $+9 \mathrm{ft} 6$ in. to $+10.0 \mathrm{ft}$ O.D. Stratigraphic sequence: surface at $+18.5 \mathrm{ft}$ O.D.; made ground, $4 \mathrm{ft}$; silty marine clay, $5 \mathrm{ft}$; peat, 9 to $10 \mathrm{ft}$; grey-blue clay, ca. $12 \mathrm{ft}$; sand and gravel. Evidence for sequence was found parallel with coast for more than $1 / 2 \mathrm{mi}$. Marine origin of clays was proved by abundance of marine diatoms (det. G. H. Evans). Coll. 1962 by Judith Turner, Botany School, Cambridge. Comment: marine beds overlying peat at comparable heights above O.D., have been reported from various sites on neighbouring coast of S Wales, but only the pollen-analyses of von Post from peat at Blackpill have so far suggested a date, in this case the Iron Age (Godwin, 1940a).

\section{Q-690. Amberley Wild Brooks, Sussex. No. 1}

Phragmites peat $\left(50^{\circ} 55^{\prime} 20^{\prime \prime} \mathrm{N}\right.$ Lat, $0^{\circ} 31^{\prime} 50^{\prime \prime} \mathrm{W}$ Long). Amberley Wild Brooks is an extensive tract of alluvium lying within chalk ridge of South Downs where it is cut by the Arun Gap. A. R. Clapham and H. Godwin have established that area is occupied by deep silty clays extending to height of ca. +3 to $+8 \mathrm{ft}$ O.D., capped by residue of a former raised-bog. Silty clays were product of a marine transgression, a tentative date for which (the beginning of transition Zone VII/VIII) was provided by pollen-analyses (Godwin, 1943). Sequence then described was: $0-100 \mathrm{~cm}$, Molinia-moss peat; $100-250 \mathrm{~cm}$, Phragmites peat with abundant Betula in upper part; $250-385 \mathrm{~cm}$, blue clay; $385 \mathrm{~cm}$, sand. 
Sample is from contact of Phragmites peat and underlying blue clay at +5 ft O.D. Coll. April 1962 by D. M. Churchill. Comment: $\mathrm{C}^{14}$ date corresponds with Late Bronze Age and agrees with pollen-analytic inference; it confirms that local expansion of the beech (Fagus) on the South Downs was Iron Age or later.

\section{Chapel Point, Lincolnshire series}

H. H. Swinnerton of Nottingham Univ. established stratigraphic sequence of postglacial beds exposed on foreshore near Chapel Point, near Chapel St. Leonards, Lincolnshire $\left(53^{\circ} 14^{\prime} \mathrm{N}\right.$ Lat, $0^{\circ} 21^{\prime} \mathrm{W}$ Long $)$. A basal peat bed with oak trees in situ lies upon boulder clay and is separated by erosion surface from overlying 'Triglochin Clay', a salt marsh deposit which passes upwards through Phragmites clays (brackish water) to a thin upper peat bed containing wood of Salix and Taxus. Upper peat surface, which lies close to mean sealevel, bears remains of salt-making industry of Halstatt type (opening of the Iron Age). A strong erosion cut channels through upper peat (and beds below) and was succeeded by 'Scrobicularia Clays,' more marine in character than 'Triglochin Clay.' Pollen-analyses of these peat beds were made during studies of deposits of Fenland basin (of which Lincolnshire coast deposits can be considered an extension) by Godwin and Clifford (1938) and subsequently in relation to deposits of Ancholme valley (Smith, 1958). Wood from upper peat bed coll. 1953 by Smith has been dated, Q-81, $2455 \pm 110$ B.P. (Cambridge III). D. M. Churchill has now coll. further material to date more precisely the marine contacts.

\section{Q-687. Chapel Point, Lincolnshire. No. 3}

$2630 \pm 110$ 680 в.с.

Scrobicularia plana shells coll. from Scrobicularia Clay where it truncated, in a narrow channel, the Upper Peat, at $+1.3 \mathrm{ft} f t$ O.D. Shells were in position of growth with Cardium edule and Macoma balthica; they probably grew at a level within contemporary neap tide range and should date the transgression that laid down the Scrobicularia Clay. Coll. Sept. 1962.

Q-688. Chapel Point, Lincolnshire. No. 4

$2630 \pm 110$ 680 в.c.

Scrobicularia plana shells coll. from Scrobicularia Clay at bottom of erosion channel cut down into leached Chalky Boulder Clay at $-9 \mathrm{ft}$ O.D. Base of channel probably lies near base level for channel erosion and corresponds with contemporary limit of low spring tides. If so it represents a contemporary sealevel some $7 \mathrm{ft}$ higher than that of today. Coll. Oct. 1961.

\section{Q-686. Chapel Point, Lincolnshire. No. 2}

$3340 \pm 110$

Salt-marsh peat from base of upper peat at contact with underlying Phragmites clay (0 ft, O.D.). Presence of such such plants as Suaeda maritima and Salicornia sp in Triglochin Clay suggests deposition near high spring tide level: today high spring tide is some $16 \mathrm{ft}$ higher. Coll. Oct. 1961.

Comment on Chapel Point series: dates for Q-687 and Q-688 are identical and indicate that little time, if any, elapsed between cutting the erosion channels and deposition of the Scrobicularia clay. Terminal date provided for upper 
peat agrees reosonably well with age determination Q-81 (see above) and accords with record of Halstatt industry upon it; the peat cannot be RomanoBritish. Q-686 indicates that formation of upper peat began in middle Bronze Age time; thus upper peat here falls within period of formation of upper peat of Fenland basin, a period thought to have seen at least local marine retrogression (Godwin, 1940b). In Humber-Ancholme estuary is good evidence (Smith, 1958) that a marine transgression took place close to Bronze-Age/Iron-Age transition, for on brush-wood peat surface below estuarine clays pottery of this period has been found, and a wooden trackway dated $2552 \pm 120$ (Q-77). Also within these clays were found two monoxylous boats dated $2796 \pm 100$ (Q-79) and 2784 \pm 100 (Q-78), whilst the sewn boat from N. Ferriby appeared to rest on upper surface of same clays and had date of $2700 \pm 150$ B.P. (BM-58) . Aggregation of these dates strongly indicates short marine transgression close to Bronze Age/Halstatt transition and Scrobicularia clays can be referred to this episode between ca. 2800 and 2550 B.P.

\section{Q-620. Moreton, Cheshire. No. 1}

$3695 \pm 110$

$3680 \pm 110$

1745 в.c.

1730 в.c.

Wood from $14 \mathrm{ft}$ tree trunk $\left(53^{\circ} 24^{\prime} 30^{\prime \prime} \mathrm{N}\right.$ Lat, $3^{\circ} 7^{\prime} \mathrm{W}$ Long $)$, found at Reeds Lane, Moreton, near Leasowe, Cheshire, lying horizontally in peat bed at $+10 \mathrm{ft}$ O.D., with roots projecting into overlying bed of silty clay extending to surface at $+14 \mathrm{ft}$. O.D. Twenty yards $\mathrm{E}$ the same peat bed was overlain by grey clay containing Scrobicularia plana. Tree may thus date a relatively late rise in sealevel. Coll. G. R. Tresise, City of Liverpool Mus. Comment: result shows that marine trangression at $+10 \mathrm{ft}$ must have taken place here not before early Bronze Age. Site is within $1200 \mathrm{yd}$ of present coast line and is probably related to peat beds exposed on foreshore at Leasowe; on nearby coast of N Wales two coastal peat beds occur on the shore separated by estuarine clays from which both Neolithic stone axes and bronze artifacts have been reported.

\section{Q-736. La Grande Mare, Guernsey, C.I. No. $1 \quad 3180 \pm 110$ \\ 1230 в.C.}

Phragmites peat $\left(49^{\circ} 27^{\prime} 58^{\prime \prime} \mathrm{N}\right.$ Lat, $2^{\circ} 36^{\prime} 20^{\prime \prime} \mathrm{W}$ Long), from top of peat which fills the valley and is overlain by sands, silts, and minor peat bands; taken from the contact at $+6 \mathrm{ft}$ O.D., with the overlying grey silty clay, which has a brackish water diatom flora that reflects the rise in sealevel. Coll. March 1963 by D. M. Churchill.

General Comment on Land-and Sealevel series: some evidence now presented indicates a general rise in sealevel in $\mathrm{S}$ and $\mathrm{W}$ Britain during Late Bronze Age (950 to 670 B.c.). Estimation of absolute height of sealevel is made difficult by large and variable tidal ranges on British coasts, although it is clear that marine influence at this time extended to about $+10 \mathrm{ft}$ O.D. in some places.

BRECKLAND SOIL PROFILES

R.M.S. Perrin of Univ. School of Agriculture, Cambridge, in the course of research into the pedogenesis of humus podsolic soils in the Breckland region of East Anglia, has submitted two series of samples with the object of learning 
something of the age of the podsolisation. Soils are mostly derived from till and outwash deposits of the Gipping glaciation or reworked products of that decalcified till, but all are very sandy. Pollen-analytic evidence suggests that podsolisation in the region may have accelerated with the Neolithic and subsequent disforestation. Each air-dried sample from the B2 (illuviation) horizon was extracted with $5 \% \mathrm{NaOH}$; the colloids were flocculated with $\mathrm{HCl}$, washed, filtered, dried and ultimately combusted.

Although the activity of each soil sample is expressed as a $\mathrm{C}^{14}$ age, this age does not date the podsol so much as demonstrate minimum age for commencement of podsolisation in the profile from which it was taken, since downward movement of humus colloids and their breakdown must be going on together. Of the two series Brandon series represents the most strongly developed (and hence perhaps oldest) humus-iron podsol of the region; in Santon series the podsolisation is less well developed. Coll. by R. M. S. Perrin, A. Hodge and E. H. Willis (Perrin, Willis and Hodge, 1964).

\section{Brandon series}

Q-716. Brandon, Suffolk. No. 1

$1583 \pm 180$ в.P. Humus from B horizon of podsol $\left(52^{\circ} 26^{\prime} \mathrm{N}\right.$ Lat, $0^{\circ} 36^{\prime} \mathrm{E}$ Long).

Q-717. Brandon, Suffolk. No. 2

$2856 \pm 180$ B.P. Humus from B horizon of podsol $\left(52^{\circ} 26^{\prime} \mathrm{N}\right.$ Lat, $0^{\circ} 37^{\prime} \mathrm{E}$ Long).

Q-771. Brandon, Suffolk. No. 3

$2460 \pm 200$ в.P. Santon series

Q-718. Santon, Elveden, Suffolk

$2854 \pm 180$ B.P. Humus from B horizon of podsol ( $52^{\circ} 24^{\prime} \mathrm{N}$ Lat, $0^{\circ} 39^{\prime} \mathrm{E}$ Long).

\section{Q-719. West Tofts, Norfolk}

$2019 \pm 180$ в.P.

Humus from B horizon of podsol $\left(52^{\circ} 29^{\prime} \mathrm{N}\right.$ Lat, $0^{\circ} 43^{\prime} \mathrm{E}$ Long).

Comment: $\mathrm{C}^{14}$ assays confirm the field impression that these are old soils. Podsolisation clearly must have been initiated at least as early as 2500 B.P., and is likely to have been advanced by then, as the effect of contamination by normal soil-forming processes would be to reduce apparent age.

\section{Le Moura, Biarritz series}

FRANCE

F. Oldfield of Univ. Dept. of Geog., Leicester in August 1958 studied the developmental history of a postglacial valley mire, near the Gare de la Nègresse, Le Moura near Biarritz in SW France $\left(43^{\circ} 25^{\prime} \mathrm{N}\right.$ Lat, $1^{\circ} 32^{\prime} \mathrm{W}$ Long). Having determined by pollen analyses secured by Hiller peat auger in center of mire, that deposits embraced a considerable part of the postglacial period, Mr. Oldfield dug a deep pit near the boring and extracted a continuous peat monolith in which the main pollen-analytic horizons were id. by supplementary analyses. Slices of peat $3 \mathrm{~cm}$ thick from three such horizons were sent to us for $\mathrm{C}^{14}$ assay. Depth in $\mathrm{cm}$ from the surface is given in each heading. 


\section{Q-617. Le Moura, FPM $20(274 \mathrm{~cm})$}

Cladium peat with remains of Potentilla palustre and Hydrocotyle palustris, immediately after first postglacial maximum of Corylus in the pollen analyses and possibly equivalent to beginning of British Zone VI. Comment: result is as old or older than that for the Zone IV $/ \mathrm{V}$ boundary in Britain (cf. Scaleby Moss, Q-154, 155; Thatcham, Q-650, 677; Port Talbot, Q-661; Star Carr, Q-14).

\section{Q-614. Le Moura, FPM $13+14(172 \mathrm{~cm})$}

$7680 \pm 140$ 5740 в.c.

Humified Cladium peat immediately below a very humified Calluna layer 50 to $60 \mathrm{~cm}$ thick, just below a sharp rise in pollen of Pinus sylvestris to a late Zone VI maximum (in terms British pollen zone sequence). Both events may register a Late Boreal drying out of the mire. Comment: conjecture is supported.

\section{Q-612. Le Moura, FPM $8(109 \mathrm{~cm})$}

$6295 \pm 130$ 4345 в.c.

Very oxidised and woody Sphagnum-Calluna peat, at bottom of rise in Alnus pollen curve, just below a suspected hiatus in the sequence. May represent the Boreal/Atlantic transition. Comment: $\mathrm{C}^{14}$ date makes this horizon synchronous with the British Zone VIIa (Atlantic).

\section{Q-610. Le Moura, FPM $4(98 \mathrm{~cm})$}

$$
\begin{aligned}
& \mathbf{5 8 6 5} \pm 120 \\
& \mathbf{3 9 1 5} \text { в.C. }
\end{aligned}
$$

Fresh sedge peat from flooding horizon with Potamogeton sp., Potentilla palustre, and Cladium mariscus above a highly humified peat with oxidized remains of Calluna. Comment: would be synchronous with later part of British Zone VIIa (Atlantic).

\section{POLAND \\ Q-709. Lake Pilakno, Rybno, Mragowo

$$
2180 \pm 100
$$$$
230 \text { B.c. }
$$

Wood $\left(53^{\circ} 47^{\prime} \mathrm{N}\right.$ Lat, $21^{\circ} 10^{\prime} \mathrm{E}$ Long), $143 \mathrm{~m}$ above sealevel, part of wooden post from an archaeological site (AR 1; METR, 13; WARSTWA II). Although post is associated with Late Bronze Age in Poland, pollen-analytic studies of Michael Dąbrowski indicate that it may correspond in age with Early Iron Age in W Europe. Coll. July 1961 by M. Dabrowski, Univ. Sub-dept. of Quaternary Research. Comment: expectation is supported by $\mathrm{C}^{14}$ determination, which also gives absolute age at one horizon in local pollen-analytic sequence.

\section{MISCELLANEOUS SAMPLES}

Lotus Seeds

Biologists are deeply interested in longevity of seeds; the greatest fully authenticated ages for germinating seeds are believed to be for Albizzia sp. ( $147 \mathrm{yr}$ ), seeds of which, coll. in China in 1793, germinated on British Mus. herbarium sheets after soaking in the air raid fire of Sept. 1940, and for Nelumbium sp. (237 yr), a 'seed' of which from the Hans Sloane collection of 
the British Mus. (1705) was germinated in 1942. Claims were however made by I. Ohga of a very much greater age than this for 'seeds' of Nelumbium nucifera recovered from the muds of a drained lake in Southern Manchuria. A sample of these 'seeds' was dated in Dr. Libby's Chicago Lab. (C-629, 1040 \pm 210 B.P.: Libby, 1955). A check determination seemed advisable, and Professor Libby kindly sent us the residue of the charcoal from which his determinations had been made: this is the material for Q-679.

Professor Libby also sent us the charcoal of his determination (C-688, $3075+180$ ) of wood from a prehistoric canoe found in lake deposits along with receptacles and some viable seeds of Lotus: this charcoal constitutes Q-704.

\section{Q-704. Kemigawa, nr. Tokyo, canoe (Chaney $3195 \pm 110$ seeds) \\ 1245 в.c.}

Charcoal on which Libby based his C-688 date (3075 \pm 180 в.P.). Wood from prehistoric canoe found $20 \mathrm{ft}$ below surface. "Associated with the remains of the canoe." I. Ohga found three viable seeds of Lotus nucifera and many receptacles of that plant in 1951, and the sample was forwarded through R. W. Chaney. Comment: our age determination of Q-704 corresponds very well with that reported by Libby and satisfactorily dates the boat. Even jointly however they yield no evidence of the age of the three Lotus seeds that Dr. Ohga grew. We are not told of the circumstances of the recovery and we are all familiar with the way in which ancient tree-stumps and similar cumbrous wreckage may lie on a lake bed and come to be associated with the modern plant and animal life of a lake or estuary when the muds are moved by current action.

\section{Q-679. Manchurian Lotus 'seeds'}

$100 \pm 60$

\section{A.D. 1850}

Charcoal on which Libby based his C-629 date: forwarded to us 21 August 1962. Prepared from combustion of fruits of Nelumbium nucifera recovered by I. Ohga from peat deposits in Pulantien basin of S Manchuria. Similar seeds were shown by him to retain a high germinative capacity. Comment: activity of Q-679 could not be distinguished from that of our 1854 standard oak wood; we measured Professor Libby's own charcoal and cannot explain the discrepancy. None the less our result indicates that age of these Manchurian 'Seeds' is not yet known beyond doubt. Ohga found cause in the lake bed stratigraphy and local history to make him attribute (before a $\mathrm{C}^{14}$ dating was possible) a very considerable age to the Lotus seeds, and he was supported by R. W. Chaney who subm. the seeds to Dr. Libby. Having by the courteous assistance of Professor T. Jimbo, consulted published accounts of the provenance of the Lotus seeds we cannot exclude the possibility that the Manchurian lake, now cultivated, was drained quite recently and that the seeds are the product of modern growth of lilies in the lake buried partly by natural sinking into the soft lake sediments and partly by the flooding associated with the river diversion and drainage and duly recorded by Ohga. Should it again become possible to collect from the same site it would be of great interest to germinate a few score of the 'seeds' and then to dry and submit for further $\mathrm{C}^{14}$ assay the dried seeds that had individually germinated. 
Redetermination of sample from which Q-621 was taken $(1649+100$ B.P.). Matted blood, flesh and cloth from Bar Kochba Cave in W Judea (Cambridge V). Dated historically at second Jewish rebellion of A.D. 135. Purpose is to establish local age reference against which to judge samples thought to be approx. Roman in age; such procedure would help reduce errors due to past variation in atmospheric $\mathrm{C}^{14}$ activity (Willis, Tauber and Münnich, 1960).

\section{Q-720. Ingombe Ilede Mound, Lusith, N. Rhodesia}

$965 \pm 100$

Wood charcoal ( $16^{\circ} 10^{\prime} \mathrm{S}$ Lat, $28^{\circ} 47^{\prime} \mathrm{E}$ Long), from Iron Age site. Cross-check with SR-23 dated at A.D. $800 \pm 100$ by $\mathrm{C}^{14}$ dating lab. of Univ. of Rhodesia and Nyasaland. Age conflicted with supposed archaeological age of sample, A.D. 1600-1700. Coll. 1961 by B. Fagan and sent to Cambridge by E. R. Swart, Dept. of Chemistry, Univ. of Rhodesia and Nyasaland. Comment: result confirms SR-23 determination.

\section{Q-689. Gibraltar Point, Lincolnshire, $\quad \mathrm{C}^{14} \delta=+95.4 \%$ Scrobicularia plana}

Shells of living Scrobicularia plana coll. between neap tide limits on mud flat. Coll. Oct, 1961 by D. M. Churchill. Comment: high $\Delta$ value shows that such material cannot be used to provide recent standard for shell age determinations, presumably because of enrichment by $\mathrm{C}^{14}$ from recent rise in atmospheric activity.

\section{ATMOSPHERIC RADIOCARBON}

A series of measurements was made of lower stratospheric $\mathrm{C}^{14}$ activity from early March 1962 to April 1963. From March to June 1962, sampling was made weekly, thence monthly until February 1963 when intervals were reduced to two weeks. Latter period coincided with the breaking up of the circumpolar vortex in 1963 and the consequent injections of air from higher altitudes. Twenty-four flying sorties were made, two being devoted entirely to control measurements to determine what leakage, if any, occurred during the climb to altitude and the subsequent descent. Atmospheric $\mathrm{CO}_{2}$ was absorbed onto $1 / 16$ th in. pellets of molecular sieve, Linde Type $4 \mathrm{~A}$ (sodium aluminium silicate) enclosed in copper mesh baskets. Eight baskets could be fitted into each sampling duct, built as extension to the wing-tip fuel tanks of a Canberra bomber of the R.A.F. On most occasions, only one duct was opened, the other acting as control. The duct could be opened at altitude by an electrically operated rubber-covered ram controlled from the cockpit. On three sorties each duct was opened for $3 / 4$, hour at altitudes ca. $2 \mathrm{~km}$ apart.

Each basket contained $400 \mathrm{~g}$ of sieve material, and $\mathrm{CO}_{2}$ was extracted from it after sampling by baking in a radiant heat furnace at $300^{\circ} \mathrm{C}$ for 3 hours in vacuum. With the ducts open for 1 hour, an average of $4.5 \mathrm{~L}$ of $\mathrm{CO}_{2}$ per $\mathrm{kg}$ of sieve was recovered. With a partial pressure of $0.033 \mathrm{~mm}$ of $\mathrm{CO}_{2}$ at $14 \mathrm{~km}$, and average temperature of $-55^{\circ} \mathrm{C}$, the amount recovered represents 
half the saturation value for the amount of sieve used. The possibility of the sieve having a memory effect from sample to sample was investigated by adsorbing inactive $\mathrm{CO}_{2}$ onto the sieve after processing. On recovery, the gas was still inactive, showing that the previous active sample had been totally recovered. The quantity of $\mathrm{CO}_{2}$ recovered did however depend to some extent on the amount of water also adsorbed, since both are competitors for the pore spaces.

Since the counting and flying facilities were both limited, the investigation was confined to one area in space. The height was $14 \mathrm{~km}(46,000 \mathrm{ft})$, the nominal isobaric surface $150 \mathrm{mb}$, and the geographical location $54^{\circ} \mathrm{N}$ and from $2^{\circ} \mathrm{E}$ to $5^{\circ} \mathrm{W}$. Results are expressed as a permillage excess over the standard activity of $0.95 \times$ NBS oxalic acid. No attempt has been made to study isotopic fractionation, and no corrections for this have been made. The effects observed were of such a magnitude that corrections for fractionation might not be helpful.

Stratospheric Sampling Series 1962/63

\begin{tabular}{lccccc}
\hline Sample No. & Flight Date & $\begin{array}{c}\text { Altitude } \\
\text { (Kilometers) } \\
\text { (a) }\end{array}$ & $\begin{array}{c}\text { Tropopause } \\
\text { Height } \\
\text { Kilometers) } \\
\text { (b) }\end{array}$ & $\begin{array}{c}\text { Stratospheric } \\
\text { Sampling } \\
\text { Height } \\
\text { (Kilometers) } \\
\text { (a-b) }\end{array}$ & $\begin{array}{c}\delta \mathrm{C}^{14} \\
\text { per mil }\end{array}$ \\
\hline Q HF/62/0 & $13-3$ & 14.2 & 9.4 & 4.8 & 3529 \\
Q HF/62/1 & $20-3$ & 14.3 & 10.4 & 3.9 & 2000 \\
Q HF/62/2 & $27-3$ & 13.9 & 10.6 & 3.3 & 1723 \\
Q HF/62/3 & $3-4$ & 13.5 & 8.7 & 4.8 & 5882 \\
Q HF/62/4 & $17-4$ & 14.0 & 9.6 & 4.4 & 2706 \\
Q HF/62/5 & $1-5$ & 13.9 & 10.2 & 3.7 & 1235 \\
Q HF/62/6 & $10-5$ & 14.0 & 9.5 & 4.5 & 2647 \\
Q HF/62/7 & $15-5$ & 14.2 & 11.3 & 2.9 & 3765 \\
Q HF/62/8 & $22-5$ & 14.2 & 10.5 & 3.7 & 1823 \\
Q HF/62/9 & $31-5$ & 14.2 & 10.0 & 4.2 & 2588 \\
Q HF/62/10 & $5-6$ & 14.3 & 12.0 & 2.3 & 1294 \\
Q HF/62/11 & $19-6$ & 14.0 & 9.3 & 4.7 & 3470 \\
Q HF/62/12 & $24-7$ & 13.7 & 12.2 & 1.5 & 1096 \\
Q HF/62/13 & $31-8$ & 14.0 & 12.0 & 2.0 & 1717 \\
Q HF/62/14 & $28-9$ & 14.0 & 10.5 & 3.5 & 877 \\
Q HF/62/15A & $22-11$ & 14.0 & 10.6 & 3.9 & 650 \\
Q HF/62/15B & $22-11$ & 12.2 & 10.6 & 1.6 & 1055 \\
Q HF/62/16A & $18-12$ & 13.4 & 9.5 & 3.9 & 1823 \\
Q HF/62/16B & $18-12$ & 10.9 & 9.5 & 1.4 & 2754 \\
Q HF/63/17 & $29-1$ & 14.2 & 11.0 & 3.2 & 3690 \\
Q HF/63/18A & $26-2$ & 14.0 & 11.0 & 3.0 & 9022 \\
Q HF/63/18B & $26-2$ & 12.2 & 11.0 & 1.2 & 5377 \\
Q HF/63/19 & $12-3$ & 14.1 & 9.3 & 4.8 & 5854 \\
Q HF/63/20 & $27-3$ & 13.4 & 10.1 & 3.3 & 4804 \\
Q HF/63/21 & $9-4$ & 13.7 & 10.5 & 3.2 & 5386 \\
\hline
\end{tabular}

Comment: the break up of the circumpolar vortex in the spring of 1962 was particularly late, occurring around 10 May. During this period, wide variations in activity were recorded. This might be due to the passage of discrete clouds of activity entering the lower stratosphere from higher altitudes, or it might be a function of the height above the tropopause of the sampling altitude. The tropopause height varied considerably from sortie to sortie and there is some 
correlation between the activity and the height of the tropopause. Sampling at two altitudes on three sorties showed a significant vertical stratification which might be important in view of the variations observed.

From late June to November 1962, the average excess value of the activity in the lower stratosphere was little more than two to three times the excess at ground level, at that time about $+400 \%$, despite the fact that intensive weapon testing was in progress during this time. This would imply that debris from current tests was being taken up to very high altitudes where it remained as a reservoir for injections into the lower stratosphere in the following spring. From December onwards, the activity steadily grew until a record peak was observed in late February. This peak had a $\delta \mathrm{C}^{14}$ value of $+9022 \%$, but fell to more nearly 5000 in the three subsequent sorties.

\section{Acknowledgment}

We would like to acknowledge the courtesy and co-operation of the Air Ministry, the Royal Air Force, members of No 58 Squadron R.A.F. Wyton, and in particular Squadron Leader I. Pattinson of A.W.R.E. Aldermaston.

\section{Troposphere}

Measurements of ground level $\mathrm{C}^{14}$ activity were made at two-monthly intervals through 1961. In 1962, while the stratospheric measurements were in progress, ground-level sampling was less frequent and in 1963 only the summer crop level was assayed. All other sampling was carried out by direct absorption onto $1 \mathrm{~N} \mathrm{Na} \mathrm{OH}$ (Cambridge IV). An average $\delta \mathrm{C}^{13}$ value of $-21 \%$ is assumed.

$\begin{array}{llr} & \text { Date } & \Delta \text { value, \%o } \\ \text { Q A/61/1 } & \text { Jan. } & 168 \pm 10 \\ \text { Q A } / 61 / 2 & \text { March } & 213 \pm 10 \\ \text { Q A } / 61 / 3 & \text { May } & 189 \pm 10 \\ \text { Q A } / 61 / 4 & \text { July } & 240 \pm 10 \\ \text { Q A } / 61 / 5 & \text { Sept. } & 216 \pm 10 \\ \text { Q A } / 61 / 6 & \text { Nov. } & 198 \pm 10 \\ \text { Q A } / 62 / 1 & \text { Feb. } & 237 \pm 10 \\ \text { Q A } / 62 / 3 & \text { March } & 240 \pm 10 \\ \text { Q A } / 62 / 4 & \text { June } & 337 \pm 10 \\ \text { Q A/63/1 } & \text { July } & 860 \pm 20\end{array}$

Correction to Cambridge III, Radiocarbon, vol. 3, p. 60.

Q-423. Shapwick Heath, Neolithic axe site, $284 / 7 \mathrm{~cm}$.

The coordinates should read ( $51^{\circ} 9^{\prime} 13^{\prime \prime} \mathrm{N}$ Lat, $2^{\circ} 48^{\prime} 37^{\prime \prime} \mathrm{W}$ Long).

Correction to Cambridge I, American Journal of Science Radiocarbon Supplement, vol. 1, p. 69.

Q-141. Stump Cross, near Grassington, Yorkshire

The date was inadvertently given in years B.c. and should be corrected as above. Comment: date modifies the remarks originally made; it agrees well 
with expectation for age of the Mesolithic industry and considering the large error is not unreasonable for the early part of Pollen-Zone VIIa.

Date lists:

REFERENCES

British Museum II Barker and Mackey, 1960

Cambridge I

Cambridge II

Cambridge III

Cambridge IV

Cambridge V

Dublin I

\section{Godwin and Willis, 1959}

Godwin and Willis, 1960

Godwin and Willis, 1961a

Godwin and Willis, 1961b

Godwin and Willis, 1962

McAulay and Watts, 1961

Chandler, M. E. J., 1921, The Arctic Flora of the Cam Valley at Barnwell, Cambridge: Geol. Soc. London, Quart. Jour., v. 77, p. 4.

Churchill, D. M., 1962, The stratigraphy of the Mesolithic sites III and IV at Thatcham, Berkshire, England: Prehist. Soc. Proc., v. 28, p. 362. in press, The Sauveterrian Kitchen midden site at Westward Ho!: some palaeo-ecological observations and a radiocarbon age determination.

Clark, J. G. D., 1955, A microlithic industry from the Cambridgeshire Fenland and other industries of Sauveterrian affinities from Britain: Prehist. Soc. Proc., v. 21, p. 3.

1963, Neolithic bows from Somerset, England, and the prehistory of archery in north-west Europe: Prehist. Soc. Proc., v. 29, p. 50.

Godwin, H., 1940a, A Boreal transgression of the sea in Swansea Bay: New Phytologist, v. 39 , p. 370 .

- 1940b, Studies of the post-glacial history of British vegetation. III Fenland pollen diagrams; IV Post-glacial changes of relative land- and sea-level in the English Fenland: Royal Soc. [London] Philos. Trans., ser. B., v. 230, p. 239. 31, p. 199. 1960 [London] Proc., B, v. 153, p. 287 odwin, H., and Clifford, M. H., 1938, Studies of the post-glacial history of British vegetation. II Origin and stratigraphy of deposits in southern Fenland: Royal Soc. [London] Philos. Trans., ser. B, v. 229, p. 363.

Godwin, H., Walker, D. and Willis, E. H., 1957, Radiocarbon dating and Post-glacial vegetational history: Scaleby Moss: Royal Soc. [London] Proc., v. 147 B, p. 352-366.

Godwin, H., Suggate, R. P., and Willis, E. H., 1958, Radiocarbon dating of the eustatic rise in ocean level: Nature, v. 181, p. 1518.

Godwin, H., and Willis, E. H., 1959, Radiocarbon dating of the Late-glacial period in Britain: Royal Soc. [London] Proc., B, v. 150, p. 199.

Leach, A. S., 1918, Flint working sites on the submerged land bordering the Pembrokeshire coast: Geol. Soc. Proc., v. 29 , p. 46.

Libby, W. F., 1951, 1955, Radiocarbon Dating: Chicago, Univ. Chicago Press.

Morrison, M. E. S., and Stephens, N., in press, A submerged Late-Quaternary deposit at Roddan's Port on the north-east coast of Ireland (with appendices).

Perrin, R., Willis, E. H., and Hodge, A., 1964, Dating of humus podzols by residual radiocarbon activity: Nature, v. 220, p. 165.

Smith, A. G., 1958, Post-glacial deposits in south Yorkshire and north Lincolnshire: New Phytologist, v. 57, p. 19.

Stephens, N., and Collins, A. E. P., 1960, The Quaternary deposits at Ringneill Quay and Ardmillan, Co. Down: Royal Irish Acad. Proc., v. 61, sec. C, pt. 3, p. 43-77.

Wainwright, G. J., 1960, Three microlithic industries from south-west England and their affinities: Prehist. Soc. Proc., v. 26, p. 193.

Willis, E. H., Tauber, H., and Münnich, K. O., 1960, Variations in the atmospheric radiocarbon concentration over the past 1300 years: Am. Jour. Sci. Radioc. Supp., v. 2, p. 1.

Wymer, J. J., 1962, Excavations at the Mesolithic sites III and IV at Thatcham, Berkshire, England: Prehist. Soc. Proc., v. 28, p. 329. 